7. Monteiro AA, Pires RN, Persson S, Rodrigues Filho EM, Pasqualotto AC. A search for Clostridium difficile ribotypes 027 and 078 in Brazil. Braz J Infect Dis 2014;18:672-674.

8. Chiang D, Ng S, La MV, Jureen R, Lin RTP, Teo JWP. Performance assessment of the BD MAX Cdiff assay in comparison to Xpert $C$. difficile assay in a setting with very low prevalence of toxigenic Clostridium difficile PCR ribotype 027. Anaerobe 2014; 30:156-158.

9. Kok J, Wang Q, Thomas LC, Gilbert GL. Presumptive identification of Clostridium difficile strain 027/NAP1/BI on Cepheid Xpert: interpret with caution. J Clin Microbiol 2011; 49:3719-3721.

10. Griffiths D, Fawley W, Kachrimanidou M, et al. Multilocus sequence typing of Clostridium difficile. J Clin Microbiol 2010;48: 770-778.

\section{Potential Impact of Antibiotic Stewardship Programs on Overall Antibiotic Use in Adult Acute-Care Hospitals in the United States}

To the Editor-We sought to characterize the expected decline in US acute-care antibiotic prescribing resulting from new accreditation standards requiring antibiotic stewardship programs. ${ }^{1}$ We conducted a narrative review of published literature assessing the impact of antibiotic stewardship program implementation on total antibiotic prescribing in acute-care hospitals in the United States.

A PubMed search was performed using the following search strategy: antimicrobial OR antibiotic AND stewardship from January 1996 to December 2016. Finally, 12 articles and 1 abstract that reported the effect of antimicrobial stewardship programs on total antibiotic use in adult US acute-care hospitals were included. The median and interquartile range (IQR) of decline in antibiotic use observed with implementation of antibiotic stewardship programs were calculated (Table 1). If no significant decline in antibiotic use was noted, percentage decline was considered to be zero. To quantify the expected national decline in antibiotic use following the implementation of antibiotic stewardship programs, the calculated median and IQR were applied to the 2012 national estimate of adult antibiotic use in acute care hospitals obtained from the Truven Health MarketScan Hospital Drug Database (HDD). ${ }^{2}$

Most studies reported the implementation of "audit and feedback," with or without antibiotic restriction; 2 studies evaluated the effect of computerized decision support; and 1 study implemented an educational intervention pertaining to the electronic health record. The median decline in antibiotic use was $15.8 \%$ (IQR, $0-27.3 \%$ ). The national estimate of total adult antibiotic use in 2012 in US acute-care hospitals was
103 million days of therapy (DOT) or 817.8 DOT per 1,000 patient days (PD) as reported by the HDD. Widespread implementation of antibiotic stewardship programs would therefore be expected to lead to an estimated median decline of 16 million DOT (IQR, 0-28 million) in total systemic antibiotic use, or a median national target of 688.6 DOT per 1,000 PD in US adult acute-care hospitals.

None of the studies reviewed showed worsening outcomes, such as increased mortality or readmissions, consistent with a recent Cochrane review. ${ }^{3}$ Reporting clinical outcomes provides an opportunity to assess the safety and potential benefits of reducing unnecessary antibiotic use. A few studies showed no change or a decrease in Clostridium difficile infection and antibiotic-resistant pathogens, which are important metrics for assessing the patient-level impact of antibiotic stewardship. ${ }^{4}$

A publication bias toward positive results may lead to the overestimation of the effect of antibiotic stewardship programs. Hospital characteristics and types of interventions varied, as did the approaches to measurement and to reported outcomes. However, with the implementation of antibiotic stewardship programs in adult US acute-care hospitals, an estimated 15.8\% ( 16 million DOT) of total antibiotic prescribing might be avoided. This number does not include other important improvements that could be made, such as narrowing the spectrum of therapy and shortening postdischarge courses. Hospital stewardship programs should be supported in their efforts to protect patients from preventable harms caused by unnecessary antibiotic exposure.

\section{ACKNOWLEDGMENTS}

Financial support: This work was supported by the Centers for Disease Control and Prevention. The findings and conclusions in this report are those of the authors and do not necessarily represent the official position of the Centers for Disease Control and Prevention.

Potential conflicts of interest: All authors report no conflicts of interest relevant to this article.

\section{Sarah Kabbani, MD, MSc; James Baggs, PhD; Lauri A. Hicks, DO; Arjun Srinivasan, MD}

Affiliations: Division of Healthcare Quality Promotion, Centers for Disease Control and Prevention, Atlanta, Georgia.

Address correspondence to Sarah Kabbani, MD, MSc, Medical officer, Office of Antibiotic Stewardship, Division of Healthcare Quality Promotion, Centers for Disease Control and Prevention, 1600 Clifton Road MS A-31, Atlanta, GA 30329 (nfq8@cdc.gov) or to Lauri Hicks, DO, CAPT, US Public Health Service, Director, Office of Antibiotic Stewardship, Division of Healthcare Quality Promotion, Centers for Disease Control and Prevention, 1600 Clifton Road MS A-31, Atlanta, GA 30329 (auq3@cdc.gov).

Infect Control Hosp Epidemiol 2018;39:373-376

(C) 2018 by The Society for Healthcare Epidemiology of America. All rights reserved. 0899-823X/2018/3903-0027. DOI: 10.1017/ice.2017.273 
тавцE 1. Published Papers and Abstracts Evaluating Antibiotic Use Changes in Adult Acute Care Hospitals in the United States

\begin{tabular}{|c|c|c|c|c|c|c|}
\hline Reference & Time & Setting & Design & ASP Description & Result & $\begin{array}{l}\text { Decline in } \\
\text { Antibiotic Use, }\end{array}$ \\
\hline $\begin{array}{l}\text { Cook PP, et al. Reduction in broad-spectrum } \\
\text { antimicrobial use associated with no improvement } \\
\text { in hospital antibiogram. } \\
\text { J Antimicrob Chemother } 2004 .\end{array}$ & 1999-2003 & $\begin{array}{l}\text { Tertiary-care } \\
\text { teaching } \\
\text { hospital }\end{array}$ & $\begin{array}{l}\text { Prospective } \\
\text { observational } \\
\text { pre-post } \\
\text { intervention }\end{array}$ & $\begin{array}{l}\text { Antimicrobial management program provided } \\
\text { prospective audit and feedback on all patients } \\
\text { on controlled antibiotics; restricted antibiotics } \\
\text { required approval by infectious } \\
\text { disease staff. }\end{array}$ & $\begin{array}{l}\text { Average quarterly total antibiotic use } \\
\text { decreased from } 1,461 \text { to } 1,069 \\
\text { DDD/1,000 PD } \\
(P=.0007) \text {. }\end{array}$ & $26.8 \%$ \\
\hline $\begin{array}{l}\text { Cook PP, et al. Sustained reduction in antimicrobial } \\
\text { use and decrease in methicillin-resistant } \\
\text { Staphylococcus aureus and Clostridium difficile } \\
\text { infections following implementation of an } \\
\text { electronic medical record at a tertiary-care teaching } \\
\text { hospital. } \\
\text { J Antimicrob Chemother } 2011 .\end{array}$ & 2005-2009 & $\begin{array}{l}\text { Tertiary-care } \\
\text { teaching } \\
\text { hospital }\end{array}$ & $\begin{array}{l}\text { Retrospective } \\
\quad \text { observational } \\
\text { interrupted time } \\
\text { series analysis }\end{array}$ & $\begin{array}{l}\text { Evaluation of antibacterial use after electronic medical } \\
\text { record implementation, with recommended dosing } \\
\text { of antibiotics; reports generated for antibiotic } \\
\text { stewardship pharmacists; and targeted education } \\
\text { efforts }\end{array}$ & $\begin{array}{l}\text { Antibacterial agent use declined } \\
\text { from } 775.3 \text { to } 552.2 \mathrm{DDD} / 1,000 \\
\text { PD } \\
(P<.0001)\end{array}$ & $28.8 \%$ \\
\hline $\begin{array}{l}\text { Cook PP, Gooch M. Long-term effects of an } \\
\text { antimicrobial stewardship programme at a tertiary- } \\
\text { care teaching hospital. Int J Antimicrob Agents } 2015 \text {. }\end{array}$ & 2001-2013 & $\begin{array}{l}\text { Tertiary-care } \\
\text { teaching } \\
\text { hospital }\end{array}$ & $\begin{array}{l}\text { Retrospective } \\
\text { observational } \\
\text { pre-post } \\
\text { intervention }\end{array}$ & $\begin{array}{l}\text { Antibiotic stewardship program performed } \\
\text { prospective audit and feedback; restricted } \\
\text { antimicrobials required infectious disease approval; } \\
\text { electronic health records were introduced in } 2007 \text {. }\end{array}$ & $\begin{array}{l}\text { Total antimicrobial use decreased } \\
\text { from } 14,443.5 \text { to } 536.6 \mathrm{DDD} / \\
1,000 \mathrm{PD}(P<.0001)\end{array}$ & $62.8 \%$ \\
\hline $\begin{array}{l}\text { Cosgrove SE, et al. Evaluation of postprescription } \\
\text { review and feedback as a method of promoting } \\
\text { rational antimicrobial use: a multicenter } \\
\text { intervention. Infect Control Hosp Epidemiol } 2012 .\end{array}$ & 2003-2004 & $\begin{array}{l}5 \text { tertiary-care } \\
\text { hospitals }\end{array}$ & $\begin{array}{l}\text { Quasi-experimental } \\
\text { pre-post } \\
\text { intervention }\end{array}$ & $\begin{array}{l}\text { Postprescription review and feedback during } \\
\text { 6-mo intervention period in addition to } \\
\text { antimicrobial stewardship programs } \\
\text { already in place }\end{array}$ & $\begin{array}{l}\text { Comparing baseline total } \\
\text { antimicrobial days/1,000 PD to } \\
\text { intervention period. } \\
\text { Hosp A, } 395.63 \text { to } 443.30 \\
\text { Hosp B, } 548.02 \text { to } 484.01 \\
\text { Hosp C, } 474.07 \text { to } 460.80 \\
\text { Hosp D, } 522.25 \text { to } 421.42 \\
\text { Hosp E, } 473.46 \text { to } 560.87\end{array}$ & $\begin{array}{l}\text { Hosp A, } 0 \\
\text { Hosp B, } 11.7 \% \\
\text { Hosp C, } 0 \\
\text { Hosp D, } 19.3 \% \\
\text { Hosp E, } 0\end{array}$ \\
\hline $\begin{array}{l}\text { Danaher PJ, et al. The antibiotic support team-a } \\
\text { successful educational approach to antibiotic } \\
\text { stewardship. Military Med } 2009 \text {. }\end{array}$ & 2006 & $\begin{array}{l}\text { Medium-sized } \\
\text { military } \\
\text { hospital }\end{array}$ & $\begin{array}{l}\text { Randomized } \\
\text { controlled trial }\end{array}$ & Educational intervention & $\begin{array}{l}\text { DDD/patient treatment course } \\
\text { significantly lower in intervention } \\
\text { group } 6.7 \text { vs } 12.9(P=.05) .\end{array}$ & $48.1 \%$ \\
\hline $\begin{array}{l}\text { Evans RS, et al. A computer-assisted management } \\
\text { program for antibiotics and other antiinfective } \\
\text { agents. N Engl J Med } 1998 \text {. }\end{array}$ & $1992-1995$ & $\begin{array}{l}\text { Intensive care } \\
\text { unit in a } \\
\text { community } \\
\text { acute-care } \\
\text { referral } \\
\text { hospital }\end{array}$ & $\begin{array}{l}\text { Prospective } \\
\text { observational } \\
\text { pre-post } \\
\text { intervention }\end{array}$ & $\begin{array}{l}\text { Computerized decision support program for } \\
\text { anti-infectives management implemented } \\
\text { in } 1994\end{array}$ & $\begin{array}{l}\text { Mean no. of days of excessive anti- } \\
\text { infective dosage decreased from } \\
5.9 \text { to } 2.7(P<.01) \text {. }\end{array}$ & $54.2 \%$ \\
\hline $\begin{array}{l}\text { Fraser GL, et al. Antibiotic optimization. An evaluation } \\
\text { of patient safety and economic outcomes. Arch } \\
\text { Intern Med } 1997 \text {. }\end{array}$ & 1994 & $\begin{array}{l}\text { Tertiary-care } \\
\text { hospital }\end{array}$ & $\begin{array}{l}\text { Randomized } \\
\text { controlled trial }\end{array}$ & $\begin{array}{l}\text { Infectious disease fellow performed prospective audit } \\
\text { on charts of patients receiving } \geq 3 \mathrm{~d} \text { of antibiotic and } \\
\text { provided feedback; study compared intervention } \\
\text { and nonintervention group. }\end{array}$ & $\begin{array}{l}\text { Similar clinical and microbiologic } \\
\text { responses, in-hospital mortality, } \\
\text { and a trend toward a shorter } \\
\text { length of stay in intervention } \\
\text { group. } \\
\text { Antibiotic use was } 10.16 \mathrm{DDD} / 1,000 \\
\text { PD in intervention group and } \\
\text { 13.59 DDD/1,000 PD in } \\
\text { nonintervention group. }\end{array}$ & $25.2 \%$ \\
\hline $\begin{array}{l}\text { Morrill HJ, et al. Impact of a prospective audit and } \\
\text { feedback antimicrobial stewardship program at a } \\
\text { Veterans Affairs medical center: a six-point } \\
\text { assessment. PLoS One } 2016 \text {. }\end{array}$ & $2010-2013$ & $\begin{array}{l}\text { Veterans } \\
\text { Affairs } \\
\text { teaching } \\
\text { hospital }\end{array}$ & $\begin{array}{l}\text { Quasi-experimental } \\
\text { interrupted time } \\
\text { series }\end{array}$ & $\begin{array}{l}\text { Antibiotic stewardship program with infectious disease } \\
\text { pharmacist fellow who performed prospective audit } \\
\text { and feedback for } \\
\text { all patients on antibiotics for appropriateness using } \\
\text { decision support template }\end{array}$ & $\begin{array}{l}\text { No change in mortality, and a } \\
\text { decrease in median length of stay. } \\
\text { No difference in overall mean DOT/ } \\
\text { 1,000 PD. }\end{array}$ & 0 \\
\hline $\begin{array}{l}\text { Rimawi RH, et al. Impact of regular collaboration } \\
\text { between infectious diseases and critical care } \\
\text { practitioners on antimicrobial utilization and } \\
\text { patient outcome. Crit Care Med } 2013 \text {. }\end{array}$ & $2011-2012$ & $\begin{array}{l}\text { Medical } \\
\text { intensive } \\
\text { care unit in } \\
\text { a tertiary- } \\
\text { care } \\
\text { hospital }\end{array}$ & $\begin{array}{l}\text { Prospective } \\
\text { observational pre- } \\
\text { post intervention }\end{array}$ & $\begin{array}{l}\text { Infectious disease fellow reviewed the charts of patients } \\
\text { on antibiotics daily and communicated with critical } \\
\text { care team for a 3-mo intervention period. }\end{array}$ & $\begin{array}{l}\text { A reduction in length of stay, } \\
\text { mortality and days of mechanical } \\
\text { ventilation. } \\
\text { Antibiotic use decreased from } 1,590 \\
\text { to } 1,420 \text { DOT } / 1,000 \mathrm{PD} \\
(P=.03274) .\end{array}$ & $10.7 \%$ \\
\hline
\end{tabular}




\begin{tabular}{|c|c|c|c|c|c|c|}
\hline $\begin{array}{l}\text { Standiford HC, et al. Antimicrobial stewardship at a } \\
\text { large tertiary-care academic medical center: cost } \\
\text { analysis before, during, and after a 7-year program. } \\
\text { Infect Control Hosp Epidemiol } 2012 \text {. }\end{array}$ & 2001-2008 & $\begin{array}{l}\text { Tertiary-care } \\
\text { teaching } \\
\text { hospital }\end{array}$ & $\begin{array}{l}\text { Retrospective } \\
\text { observational pre- } \\
\text { post intervention }\end{array}$ & $\begin{array}{l}\text { An antimicrobial monitoring team was developed in } \\
2001 \text { and integrated into infectious disease consults } \\
\text { after } 7 \text { y; team reviewed antimicrobial orders and } \\
\text { provided recommendations, developed guidelines } \\
\text { and policies, ASP cost analysis for } 7 \text { y during and } \\
\text { after intervention. }\end{array}$ & $\begin{array}{l}\text { Decrease in total antibacterial use } \\
\text { from } 2004 \text { to } 2008 \text { by } 323 \mathrm{DDD} / \\
1,000 \mathrm{PD}(P=.03) \text {. }\end{array}$ & $27.5 \%$ \\
\hline $\begin{array}{l}\text { Stenehjem et al, Stewardship in Community Hospitals } \\
\text {-Optimizing Outcomes and Resources (SCORE): } \\
\text { a cluster-randomized controlled trial investigating } \\
\text { the impact of antibiotic stewardship in } 15 \text { small, } \\
\text { community hospitals Open Forum Infect Dis, } \\
\text { IDweek } 2016 \text { Abstract. }\end{array}$ & 2011-2013 & $\begin{array}{l}15 \text { small } \\
\text { community } \\
\text { hospitals }\end{array}$ & $\begin{array}{l}\text { Cluster randomized } \\
\text { controlled trial }\end{array}$ & $\begin{array}{l}\text { Hospitals were randomized to } 3 \text { groups and compared } \\
\text { adjusted antibiotic use ratio before and during the } \\
15-\text { mo intervention period, with increasing levels of } \\
\text { intensity of infectious disease review of data, } \\
\text { consultation; antibiotic use data were obtained } \\
\text { from NHSN AU option reporting. }\end{array}$ & $\begin{array}{l}\text { Compared adjusted antibiotic use } \\
\text { ratio. Compared to program } 1, \\
\text { program } 3 \text { reduced antibiotic use } \\
\text { by } 17 \% \text {. Program } 2 \text { did not } \\
\text { significantly reduce antibiotic } \\
\text { use. }\end{array}$ & $\begin{array}{l}\text { Program 1, 17\% } \\
\text { Program 2, } 0\end{array}$ \\
\hline $\begin{array}{l}\text { Storey DF, et al. Implementation of an antimicrobial } \\
\text { stewardship program on the medical-surgical } \\
\text { service of a 100-bed community hospital. } \\
\text { Antimicrob Resist Infect Control } 2012 \text {. }\end{array}$ & 2009-2010 & $\begin{array}{l}\text { Community } \\
\text { hospital }\end{array}$ & $\begin{array}{l}\text { Retrospective } \\
\text { observational pre- } \\
\text { post intervention }\end{array}$ & $\begin{array}{l}\text { Antimicrobial stewardship team } 16 \text {-mo intervention; } \\
\text { education, audit and feedback of charts, } \\
\text { vancomycin dosing, order sets for pneumonia; } \\
\text { severe sepsis and parenteral to oral conversion } \\
\text { protocol }\end{array}$ & $\begin{array}{l}\text { Reduction in mean monthly } \\
\text { antibacterial use decreased from } \\
1,028 \text { to } 878.7 \mathrm{DDD} / 1,000 \mathrm{PD} \\
(P=.011)\end{array}$ & $14.5 \%$ \\
\hline $\begin{array}{l}\text { Timbrook TT, Hurst JM, Bosso JA. Impact of an } \\
\text { antimicrobial stewardship program on } \\
\text { antimicrobial utilization, bacterial susceptibilities, } \\
\text { and financial expenditures at an academic medical } \\
\text { center. Hosp Pharm } 2016 \text {. }\end{array}$ & 2008-2013 & $\begin{array}{l}\text { Adult academic } \\
\text { hospital }\end{array}$ & $\begin{array}{l}\text { Retrospective quasi- } \\
\text { experimental pre- } \\
\text { post intervention }\end{array}$ & $\begin{array}{l}\text { Antibiotic stewardship program implemented 2009- } \\
2013 \text { included prospective audit and feedback, } \\
\text { preauthorization, dose optimization, guideline } \\
\text { development, and clinical pathways. }\end{array}$ & $\begin{array}{l}\text { Antibiotic utilization measured as } \\
\text { DDD } / 1,000 \text { PD decreased by } 2 \% \\
\text { from } 2008 \text { to } 2013(P=.46) \text {. }\end{array}$ & 0 \\
\hline
\end{tabular}

NOTE. DDD, defined daily dose; DOT, days of therapy; PD, patient days. 


\section{REFERENCES}

1. New antimicrobial stewardship standard. The Joint Commission website. https://www.jointcommission.org/assets/1/6/New_ Antimicrobial_Stewardship_Standard.pdf. Published 2016. Accessed November 5, 2017.

2. Baggs J, Fridkin SK, Pollack LA, Srinivasan A, Jernigan JA. Estimating national trends in inpatient antibiotic use among US hospitals from 2006 to 2012. JAMA Intern Med 2016;176:1639-1648.

3. Davey P, Marwick CA, Scott CL, et al. Interventions to improve antibiotic prescribing practices for hospital inpatients. Cochrane Database Syst Rev 2017;2:CD003543. doi: 10.1002/14651858. CD003543.pub4.

4. Moehring RW, Anderson DJ, Cochran RL, Hicks LA, Srinivasan A, Dodds Ashley ES. Expert consensus on metrics to assess the impact of patient-level antimicrobial stewardship interventions in acute-care settings. Clin Infect Dis 2017;64: 377-383.

\section{Comments on: A Model to Predict Central-Line-Associated Bloodstream Infection Among Patients With Peripherally Inserted Central Catheters: The MPC Score}

To the Editor-We read the article by Herc et $\mathrm{al}^{1}$ with great interest. Although the methodology and results of the study were very interesting, we think some methodological issues should be noted.

The results demonstrate that area under the curve (AUC) for peripherally inserted central catheter (PICC) dwell times at $6,10,14$ and 21 days were $0.70,0.75,0.77$, and 0.80 , respectively. ${ }^{1}$ The authors point out that the central-lineassociated bloodstream infections (CLABSI) risk model at dwell time of 21 days has good prediction performance because the AUC value at 21 days wasat its maximum. ${ }^{1}$ To us the most important concern is that the difference between the AUC at 14 and 21 days is negligible ( 0.77 vs 0.80 ). In other words, the CLABSI risk model at dwell times of 14 and 21 days may have the same prediction performance. We recommend that the authors try to test the statistical comparison of AUCs with available statistical methods $^{2,3}$ because empirical comparisons of AUCs may be misleading.

Although AUC analysis can produce all possible discriminative thresholds, the results of AUC analyses can be hardly translated into clinical practice. ${ }^{4}$ Net benefit methods are alternative approaches of receiver operating characteristic curve (ROC) analysis; these methods can better clarify the prediction performance of a PICC-CLABSI risk-prediction tool.

\section{ACKNOWLEDGMENT}

Financial support: No financial support was provided relevant to this article.

Potential conflicts of interest: All authors report no conflicts of interest relevant to this article.

\section{Saeid Safiri; ${ }^{1}$ \\ Erfan Ayubi ${ }^{2,3}$}

Affiliations: 1. Managerial Epidemiology Research Center, Department of Public Health, School of Nursing and Midwifery, Maragheh University of Medical Sciences, Maragheh, Iran; 2. Department of Epidemiology, School of Public Health, Shahid Beheshti University of Medical Sciences, Tehran, Iran; 3. Department of Epidemiology and Biostatistics, School of Public Health, Tehran University of Medical Sciences, Tehran, Iran.

Address correspondence to Erfan Ayubi, MSc, PhD, Department of Epidemiology, School of Public Health, Shahid Beheshti University of Medical Sciences, Tehran, Iran (aubi65@gmail.com).

Infect Control Hosp Epidemiol 2018;39:376-376

(c) 2018 by The Society for Healthcare Epidemiology of America. All rights reserved. 0899-823X/2018/3903-0028. DOI: 10.1017/ice.2018.2

\section{REFERENCES}

1. Herc E, Patel P, Washer LL, Conlon A, Flanders SA, Chopra V. A model to predict central-line-associated bloodstream infection among patients with peripherally inserted central catheters: the MPC score. Infect Control Hosp Epidemiol 2017;38: 1155-1166.

2. DeLong ER, DeLong DM, Clarke-Pearson DL. Comparing the areas under two or more correlated receiver operating characteristic curves: a nonparametric approach. Biometrics 1988;44: 837-845.

3. Hanley JA, McNeil BJ. A method of comparing the areas under receiver operating characteristic curves derived from the same cases. Radiology 1983;148:839-843.

4. Halligan S, Altman DG, Mallett S. Disadvantages of using the area under the receiver operating characteristic curve to assess imaging tests: a discussion and proposal for an alternative approach. Eur Radio 2015;25:932-939. 